\title{
Changes in the spectrum of salivary cytokines in recurrent stomatitis in children
}

\section{Alisher MURTAZAYEV ${ }^{1}$ Alisher NORBUTAYEV 2}

Samarkand State Medical Institute

\section{ARTICLE INFO}

\section{Article history:}

Received September 2020

Received in revised form 15

September 2020

Accepted 25 September

2020

Available online

1 October 2020

\section{Keywords:}

Acute and chronic recurrent

stomatitis

Children

Cytokines

Immunoregulatory

mechanisms.

\begin{abstract}
The concentration of the level of cytokines in saliva depends on the form of stomatitis, which is confirmed by the presence of a relationship between the concentrations of TNF $\alpha$ and IL-1 $\beta$, and this relationship is direct and varies depending on the form of stomatitis, which indicates a violation of immunoregulatory mechanisms in chronic recurrent forms of stomatitis
\end{abstract}

2181-1415/C 2020 in Science LLC.

This is an open access article under the Attribution 4.0 International (CC BY 4.0) license (https://creativecommons.org/licenses/by/4.0/deed.ru)

\section{Болаларда қайталанувчи стоматитларда сўлакда цитокин спектрининг ўзгариши}

\section{Калит сузлар:}

Ўткир ва сурункали қайталанувчи стоматит

Болалар

Цитокинлар

Иммунорегулятор

механизмлар

\begin{abstract}
АННОТАЦИЯ
Мақола Россияда афсонавий фундаментал ва амалий машхур тушунчаларни ривожлантириш муаммоларига бағишланган. Рус миллий маданиятининг турли шаклларидаги таниқли олимларнинг асарлари ўрганилмоқда, бугунги кунгача асосий аксиомаларга айланган ва адабий асар мифологиясини ўрганишга имкон берган классик фаннинг ютуқлари ўрганилмоқда. Олимлар ёзувлари асосида муаллиф замонавий афсона тушунчаси ва унинг функционал хусусиятларини ажратиб кўрсатишга харакат қилди
\end{abstract}

\footnotetext{
${ }^{1}$ Department of Stomatology №1, Samarkand State Medical Institute, Samarkand, Uzbekistan

2 Department of Stomatology №1, Samarkand State Medical Institute, Samarkand, Uzbekistan
} 


\section{Изменения спектра цитокинов слюны при рецидивирующих стоматитах у детей}

\section{Ключевые слова:}

Острый и хронический

рецидивирующий

стоматит

Дети

Цитокины

Иммунорегуляторные

механизмы

\begin{abstract}
АННОТАЦИЯ
Концентрации уровня цитокинов в слюне зависят от формы стоматитов, что подтверждается наличием взаимосвязи между концентрациями TNF $\alpha$ и IL-1 $\beta$, причем эта зависимость прямая и изменяется в зависимости от формы стоматитов, что свидетельствует о нарушении иммунорегуляторных механизмов, при хронических рецидивирующих формах стоматитов.
\end{abstract}

Relevance. The study of the role of cytokines in the secretion of the oral cavity in children with acute and chronic recurrent stomatitis is one of the fundamental points for understanding the pathogenesis of bacterial and viral infections $[1,2]$. For clinical practice, the study of the cytokine status of the oral secretion is difficult to overestimate, since it reflects the individual primary response to a bacterial and viral agent, allows you to assess the nature of the process, predict the outcome of the disease in many bacterial and viral infections of the oral cavity, and also allows you to objectively evaluate the effectiveness treatment [2,5].The clinical study of the level of cytokines in the oral cavity is devoted to isolated works related to the pathology of the oral mucosa $[3,4]$.

In this regard, the goal of our study was: To study the spectrum of cytokines of the oral cavity secretion in children and their prognostic value in the pathogenesis of acute and chronic recurrent stomatitis.

\section{MATERIALS AND METHODS}

The study is based on a clinical and laboratory examination, 74 children with acute and chronic recurrent stomatitis who applied to a dental clinic. All examined children were divided into 2 groups according to the forms of stomatitis. Group I - 52 children with acute stomatitis and Group II - 22 children with chronic recurrent stomatitis, 20 healthy children of comparable age made up the control group. All children underwent a study of the cytokine profile of the secretions of the oral cavity. Analyzed the content of three cytokines-IL-1 $\beta$ TNF $\alpha$ and IL-4 in the projection and severity and phase of the disease. They were selected as probable markers of total (IL-4, TNF $\alpha$ ) and allergen (IgE) -dependent phlogogenicity (IL-4).

\section{RESULTS AND DISCUSSION}

In the group of healthy children, the content of IL-1 $\beta$ in saliva was $21.8 \pm 1.80 \mathrm{pg} /$ $\mathrm{ml}$. For groups of patients, the following results were obtained: group $2196.0 \pm 20.76 \mathrm{pg}$ / ml, group $1128.0 \pm 14.04 \mathrm{pg} / \mathrm{ml}$ (for all parameters $\mathrm{p}<0.001$ ). Differences between groups are significant $(\mathrm{p}<0.001)$. In the control group, the content of TNF $\alpha$ in saliva was $-27.3 \pm 2.55 \mathrm{pg} / \mathrm{ml}$. For groups of patients, the following results were obtained: group 2 - $95.7 \pm 9.16 \mathrm{pg} / \mathrm{ml}$, group $1-54.6 \pm 4.56 \mathrm{pg} / \mathrm{ml}$ (for all indicators, P <0.001). In healthy children, the content of IL- 4 in saliva was $6.2 \pm 0.41 \mathrm{pg} / \mathrm{ml}$. For groups of patients, the following results were obtained: group $2-19.5 \pm 1.79 \mathrm{pg} / \mathrm{ml}$, group 1 $12.7 \pm 1.02 \mathrm{pg} / \mathrm{ml}$ (for all parameters $\mathrm{p}<0.001$ ). The data obtained develop the idea 
that the state of real homeostasis can be an indicator of distant pathological processes, including allergic inflammation. In the present study, this was manifested in the study of the cytokine profile (IL1 $\beta, \mathrm{TNF} \alpha$ and IL-4) of the oral secretion in children with stomatitis. It was found that in the acute phase of the disease, the content of all three cytokines increased significantly. The most significant and permanent increase was noted for IL-1 $\beta$.In patients with severe course, the indicators were higher than in moderate and mild forms of the disease; for the last two groups, no significant differences were found. This was observed for all three cytokines. The difference is that mild forms of the disease do not usually cause an increase in serum levels of IL-1 $\alpha$ and TNF $\alpha$.

\section{CONCLUSIONS}

1. Our results show a significant dependence of the concentration of the level of cytokines in saliva on the form of stomatitis.

2. The results of the study confirm the existence of a relationship between the concentrations of TNF $\alpha$ and IL-1 $1 \beta$, and this relationship is direct and varies depending on the form of stomatitis, which indicates a violation of the immunoregulatory mechanisms in chronic recurrent forms of stomatitis.

\section{References}

1. Ариненко Р.Ю., Аникин В.Б., Головкин В.И. Система интерферона: первая линия защиты организма // TerraMedical. - 2007. - №4. - C.11-14.

2. Конусова В.Г., Симбирцев А.С., Кетлинский С.А. Продукция интерлейкина-1 моноцитами периферической крови у детей с респираторными заболеваниями // Иммунология. - 2002. - №1. - С.52-55.

3. Фазылова Ю.В., Рувинская Г.Р., Ковязина С.Б. Эффективность озонотерапии в лечении поражений слизистой ротовой полости // Современные проблемы науки и образования. - 2013. - №6 - С. 36-38.

4. J.E.Dahnhardt, T.Jaeggi, A. Lussi Treating open carious lesions in anxious children with ozone // A prospective controlled clinical study. - 2006. - №19. -P. 267-270 